Biogeosciences, 10, 5311-5324, 2013

www.biogeosciences.net/10/5311/2013/

doi:10.5194/bg-10-5311-2013

(C) Author(s) 2013. CC Attribution 3.0 License.

\title{
Nested atmospheric inversion for the terrestrial carbon sources and sinks in China
}

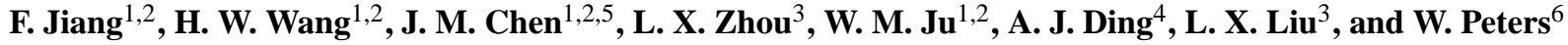 \\ ${ }^{1}$ Jiangsu Provincial Key Laboratory of Geographic Information Science and Technology, Nanjing University, Nanjing, China \\ ${ }^{2}$ International Institute for Earth System Science, Nanjing University, Nanjing, China \\ ${ }^{3}$ Chinese Academy of Meteorological Sciences (CAMS), China Meteorological Administration (CMA), Beijing, China \\ ${ }^{4}$ Institute for Climate and Global Change Research \& School of Atmospheric Sciences, Nanjing University, Nanjing, China \\ ${ }^{5}$ Department of Geography and Program in Planning, University of Toronto, Toronto, Canada \\ ${ }^{6}$ Department of Meteorology and Air Quality, Wageningen University, Wageningen, the Netherlands
}

Correspondence to: F. Jiang (jiangf@ nju.edu.cn)

Received: 15 December 2012 - Published in Biogeosciences Discuss.: 25 January 2013

Revised: 27 June 2013 - Accepted: 2 July 2013 - Published: 6 August 2013

\begin{abstract}
In this study, we establish a nested atmospheric inversion system with a focus on China using the Bayesian method. The global surface is separated into 43 regions based on the 22 TransCom large regions, with 13 small regions in China. Monthly $\mathrm{CO}_{2}$ concentrations from 130 GlobalView sites and 3 additional China sites are used in this system. The core component of this system is an atmospheric transport matrix, which is created using the TM5 model with a horizontal resolution of $3^{\circ} \times 2^{\circ}$. The net carbon fluxes over the 43 global land and ocean regions are inverted for the period from 2002 to 2008. The inverted global terrestrial carbon sinks mainly occur in boreal Asia, South and Southeast Asia, eastern America and southern South America. Most China areas appear to be carbon sinks, with strongest carbon sinks located in Northeast China. From 2002 to 2008, the global terrestrial carbon sink has an increasing trend, with the lowest carbon sink in 2002. The inter-annual variation (IAV) of the land sinks shows remarkable correlation with the El Niño Southern Oscillation (ENSO). The terrestrial carbon sinks in China also show an increasing trend. However, the IAV in China is not the same as that of the globe. There is relatively stronger land sink in 2002, lowest sink in 2006, and strongest sink in 2007 in China. This IAV could be reasonably explained with the IAVs of temperature and precipitation in China. The mean global and China terrestrial carbon sinks over the period 2002-2008 are $-3.20 \pm 0.63$ and $-0.28 \pm 0.18 \mathrm{PgC} \mathrm{yr}^{-1}$, respectively. Considering the carbon emissions in the form of reactive biogenic
\end{abstract}

volatile organic compounds (BVOCs) and from the import of wood and food, we further estimate that China's land sink is about $-0.31 \mathrm{PgC} \mathrm{yr}^{-1}$.

\section{Introduction}

Carbon dioxide $\left(\mathrm{CO}_{2}\right)$ and other greenhouse gases emitted from human activities are the main cause of global warming (IPCC, 2007). In 2008, the carbon emissions from fossil fuel combustion, cement production and land use change reached $10 \mathrm{PgC} \mathrm{yr}^{-1}$. About $40 \%$ of these $\mathrm{CO}_{2}$ were detained in the atmosphere, leading to the increase in atmospheric $\mathrm{CO}_{2}$ concentration at an unprecedented rate (about $\left.1.8 \mathrm{ppm} \mathrm{yr}^{-1}\right)(\mathrm{Le}$ Quéré et al, 2009). At the present, China has become the largest $\mathrm{CO}_{2}$ emitter in the world, and will continue to increase in the near future due to population growth and economic development (Leggett, 2011).

Terrestrial ecosystems play a very important role on regulating the atmospheric $\mathrm{CO}_{2}$ concentration. In the 1990s and during 2000-2005, on average, terrestrial ecosystems absorbed $-1.0 \pm 0.6$ and $-0.9 \pm 0.6 \mathrm{PgC} \mathrm{yr}^{-1}$ carbon from the atmosphere, accounting for about $16 \%$ and $13 \%$ of the emissions from fossil fuel combustion and cement production, respectively (IPCC, 2007). During 1980-2000, the carbon sinks of forests, grasslands, and shrubs in China were $-0.075,-0.007$, and -0.014 to $-0.024 \mathrm{PgC} \mathrm{yr}^{-1}$, respectively, which in total offset $20.0-26.8 \%$ of China's industrial 
carbon emissions (Fang et al., 2007). Based on the 19992003 national forest inventory, Wang et al. (2010) calculated the carbon sink of China's forest to be $-0.21 \mathrm{PgC} \mathrm{yr}^{-1}$. Using an ecosystem model, Wang et al. (2007) simulated the forest carbon sink to be $-0.18 \pm 0.05 \mathrm{PgC} \mathrm{yr}^{-1}$ during 1988-2001, and Tian et al. (2011) simulated the China land sink to be $-0.21 \mathrm{PgC} \mathrm{yr}^{-1}$ during 1961-2005, with a range from $-0.18-0.24 \mathrm{PgC} \mathrm{yr}^{-1}$. However, since it is very difficult to obtain detailed inventories of soil carbon storage and forest resources, the carbon sink estimations based on inventories still have large uncertainties. Simulations using ecosystem models are highly dependent on model structure, model parameters and input data, and they also have large uncertainties.

Atmospheric inversion is a method that uses observed atmospheric $\mathrm{CO}_{2}$ concentrations to optimize land and ocean carbon fluxes. For this purpose, an atmospheric transport model is used to simulate the atmospheric $\mathrm{CO}_{2}$ concentration based on a prior estimate of the land and ocean fluxes. The optimization of the prior fluxes is made according to the difference between observed and simulated $\mathrm{CO}_{2}$ concentrations. With this method, many studies have been conducted to estimate the global terrestrial carbon fluxes (e.g., Enting and Mansbridge, 1989; Rayner et al., 1999a; Ciais, et al., 2000; Gurney et al., 2002; Law et al., 2003; Rödenbeck et al., 2005; Patra et al., 2005a; Rayner et al., 2008; Maki et al., 2010), and most of these studies focused on the spatial pattern of the carbon sources and sinks and the inter-annual variations. In recent years, one of the research directions of atmospheric inversion is to estimate fluxes in finer spatial resolutions (e.g., Gerbig et al., 2003; Peylin et al., 2005; Peters, et al., 2007; Schuh et al., 2010). Peters et al. (2007) developed the first global carbon assimilation system named Carbon Tracker with a focus on North America. Based on the Carbon Tracker, CarbonTracker-Europe was then developed (Peters et al, 2010), which is focused on Europe. Deng et al. (2007) developed a nested atmospheric inversion method in which the central region is divided into a number of cells, while large regions remain the same outside of the central region, and the inversion for large and small regions is done simultaneously. With this method, much more detailed carbon fluxes of the areas of concern could be inverted compared to the global large region scheme, and the uncertainty caused by setting boundary conditions in regional inversion could be reduced. Based on this method, Deng et al. (2007) successfully inverted carbon sources and sinks for North America in a relatively high resolution (30 small regions). In this paper, based on the nested method, we established a China-focused nested atmospheric inversion system. Using this system, we investigate the spatial distribution of terrestrial ecosystems carbon sources and sinks in China as well as their inter-annual variations during 2002-2008. The description of the inversion system is presented in Sect. 2, and the inverted spatial patterns of terrestrial carbon fluxes as well as their inter-annual variations are presented and discussed in Sect. 3 .

\section{Inversion method}

The observed $\mathrm{CO}_{2}$ concentration at one time and one place is contributed by the transport of the fluxes from all global regions for a past period of time and the initial well-mixed $\mathrm{CO}_{2}$ concentration. The transport contributions could be expressed as a transport operator multiplied by the fluxes. So, if we have enough $\mathrm{CO}_{2}$ observations, the transport operator and the initial $\mathrm{CO}_{2}$ concentration, the fluxes could be known. In this study, we use the time-dependent Bayesian synthesis method (Rayner et al., 1999a) to solve this inversion problem. Details about this method could be found in Deng et al. (2007). The key of this method is to minimize the following cost function (Enting et al., 1995; Rayner et al., 1999a).

$J=\frac{1}{2}(\mathbf{M} s-c)^{T} R^{-1}(\mathbf{M} s-c)+\frac{1}{2}\left(s-s_{\mathrm{p}}\right)^{T} Q^{-1}\left(s-s_{\mathrm{p}}\right)$

where $\mathbf{M}$ is a matrix representing the transport operator; $c$ is the observations; $s$ is the unknown vector of the carbon fluxes of all regions at different times combined with the initial well-mixed atmospheric $\mathrm{CO}_{2}$ concentration; $s_{\mathrm{p}}$ is a priori estimation of $s$; and $R$ and $Q$ are the uncertainties of $c$ and $s_{\mathrm{p}}$, respectively. By minimizing this cost function, the posterior fluxes $s_{\text {post }}$ and their uncertainties $Q_{\text {post }}$ could be obtained as

$$
\begin{aligned}
& \boldsymbol{s}_{\text {post }}=\left(\mathbf{M}^{T} R^{-1} \mathbf{M}+Q^{-1}\right)^{-1}\left(\mathbf{M}^{T} R^{-1} c+Q^{-1} \boldsymbol{s}_{\mathrm{p}}\right), \\
& Q_{\text {post }}=\left(Q^{-1}+\mathbf{M}^{T} R^{-1} \mathbf{M}\right)^{-1} .
\end{aligned}
$$

\subsection{Inversion regions}

In this study, the global surface is separated into 43 regions based on the 22 TransCom large regions (e.g., Gurney et al., 2003), with 13 small regions in China (Fig. 1). The partition scheme in China is mainly based on land cover types (i.e., forest, crop, grass, and desert). MODIS land cover data for the year 2007 using the University of Maryland (UMD) classification scheme (Hansen, et al., 1998) were used in this study, which were obtained from http://lpdaac.usgs.gov (LP DAAC, 2001). The forest in China is separated into 5 regions: South China (region 29), Southwest China (region 30), East China (region 31), central China (region 32), and Northeast China (region 33). The crop is separated into 4 regions: Sichuan Basin (region 37), North China crop region (mainly North China plain, region 38), Yangtze Plain (region 39) and Northeast China Plain (region 40). The grass is partitioned into 3 regions: North China grass region (region 34), Southwest China grass region (region 35) and Northwest China grass region (region 36). The rest of Asia is separated into 8 regions. They are Southeast Asia, Indo-China peninsula, Indian peninsula, Japan, Korean peninsula, Mongolia, West Asia, and boreal Asia. Temperate North America is separated 


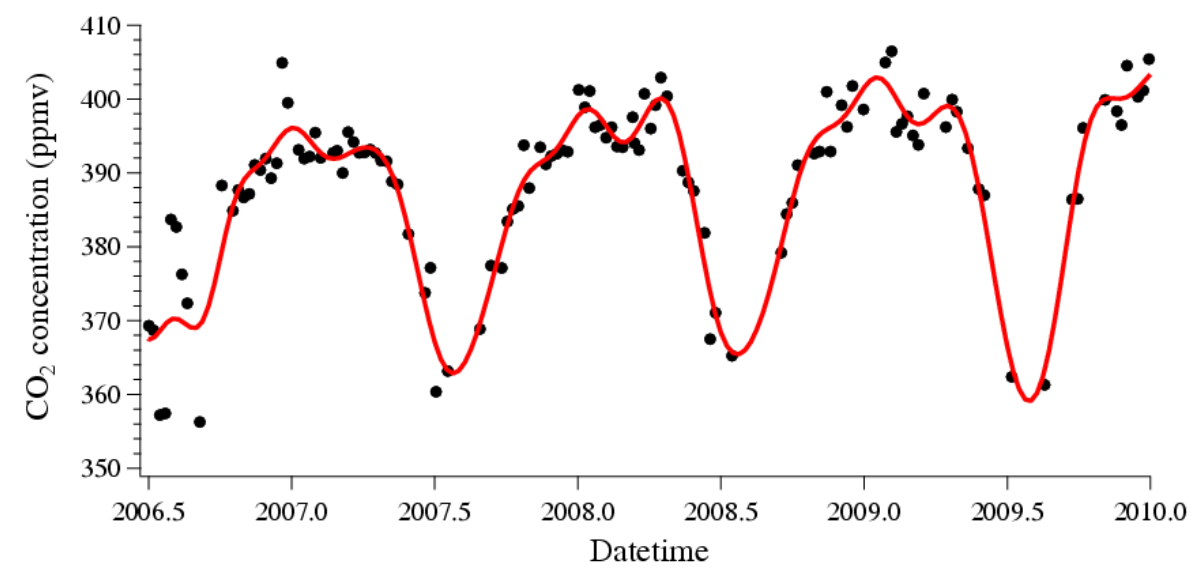

Fig. 1. Time series of the $\mathrm{CO}_{2}$ measurements at Longfengshan (LFS) in Northeast China: black points indicate weekly flask observations; red line indicates a curve fitted to the measurements.

into 2 regions due to the significant land cover difference between east and west temperate North America. In addition, Africa is partitioned into 3 regions in this study: northern Africa, tropical Africa, and southern Africa (see Fig. 2).

\subsection{Transport modeling}

Monthly transport operator M of ten years (January 2000 to December 2009) for the 43 regions is calculated using the global two-way nested transport model TM5 (Krol et al., 2005), which has been evaluated extensively and consistently and performs well on vertical and horizontal transport in ongoing intercomparisons (Stephens et al., 2007), and it has been widely used in global atmospheric chemistry studies (e.g., Houweling et al., 1998; Dentener et al., 2003; Peters et al., 2002) and atmospheric inversion research (e.g., Meirink et al., 2008; Krol et al., 2008; Peters, et al., 2007). TM5 is an off-line model that is driven by meteorological fields from the ECMWF model. In this study, TM5 is run at a horizontal resolution of $3^{\circ} \times 2^{\circ}$ around the world, and without nested domain. There are 25 vertical layers, with the model top at about $1 \mathrm{hPa}$. The ECMWF outputs with $1^{\circ} \times 1^{\circ}$ horizontal resolution, 60 vertical layers and a 3 -hour interval (for most variables) were used to drive the model.

Firstly, TM5 is modified to tag the $\mathrm{CO}_{2}$ concentrations contributed from the carbon fluxes of each region. Then, the contributions of each month and each region to the $\mathrm{CO}_{2}$ concentrations at each observation are calculated. In total, TM5 is run 120 times, and each time the model is continuously run for three years, with $1 \mathrm{Pg}$ carbon emitted from each region in the first month, and no emissions in the subsequent months. The distribution of the $1 \mathrm{Pg}$ carbon emissions in each terrestrial region is according to the annual mean net primary production (NPP) pattern, which is calculated using the BEPS model (Chen et al., 1999; Ju et al., 2006); while no distribution was considered for the ocean region. However, we assume that no carbon exchanges happen when the sea surface is covered by ice. Monthly sea ice data from the HadISST dataset (Rayner, et al., 2003) are used in this study.

TM5 is also used in forward transport simulation from January 2000 to December 2009 for two types of fluxes in the same grid system with transport operator calculations. One type of flux is (i) the Miller Carbon Tracker fossil fuel emission field, which is constructed based on CDIAC 2007 (Boden et al., 2010) and EDGAR 4 databases (Olivier and Berdowski, 2001). The emissions in 2008 and 2009 are extrapolated from the 2007 CDIAC statistics using energy consumption statistics from the BP Statistical Review of World Energy 2010. More detailed descriptions can be found in the document of Carbon Tracker (http://carbontracker.noaa.gov). The other type is (ii) the monthly mean fire emission available from the Global Emissions Fire Database version 3 (GFEDv3) (van der Werf et al., 2010). As we assume that these two fluxes have been correctly estimated, the $\mathrm{CO}_{2}$ concentrations from the contributions of these fluxes will be presubtracted in the inversion system. Hence, the matrix $\mathbf{c}$ in Eq. (1) can be further expressed as

$\mathbf{c}=\mathbf{c}_{\mathrm{obs}}-\mathbf{c}_{\mathrm{ff}}-\mathbf{c}_{\mathrm{fire}}$,

where $\mathbf{c}_{\mathrm{obs}}$ is the observed monthly $\mathrm{CO}_{2}$ concentration; $\mathbf{c}_{\mathrm{ff}}$ and $\mathbf{c}_{\text {fire }}$ are simulated ones by the forward simulation from fluxes (i) and (ii), respectively.

\subsection{Priori fluxes and their uncertainties}

Hourly terrestrial ecosystem carbon exchanges and daily carbon fluxes across the air-sea interface are considered as prior fluxes. The former is simulated using the BEPS model, which is a process-based, remote sensing data driven, and mechanistic ecosystem model (Chen et al., 1999; Ju et al., 2006). In this study, BEPS is run at $1^{\circ} \times 1^{\circ}$ resolution for 7 land cover types (i.e., evergreen coniferous forest, deciduous coniferous forest, deciduous broadleaf forest, evergreen broadleaf forest, shrub, C4 plants and others), and it is driven by NCEP 


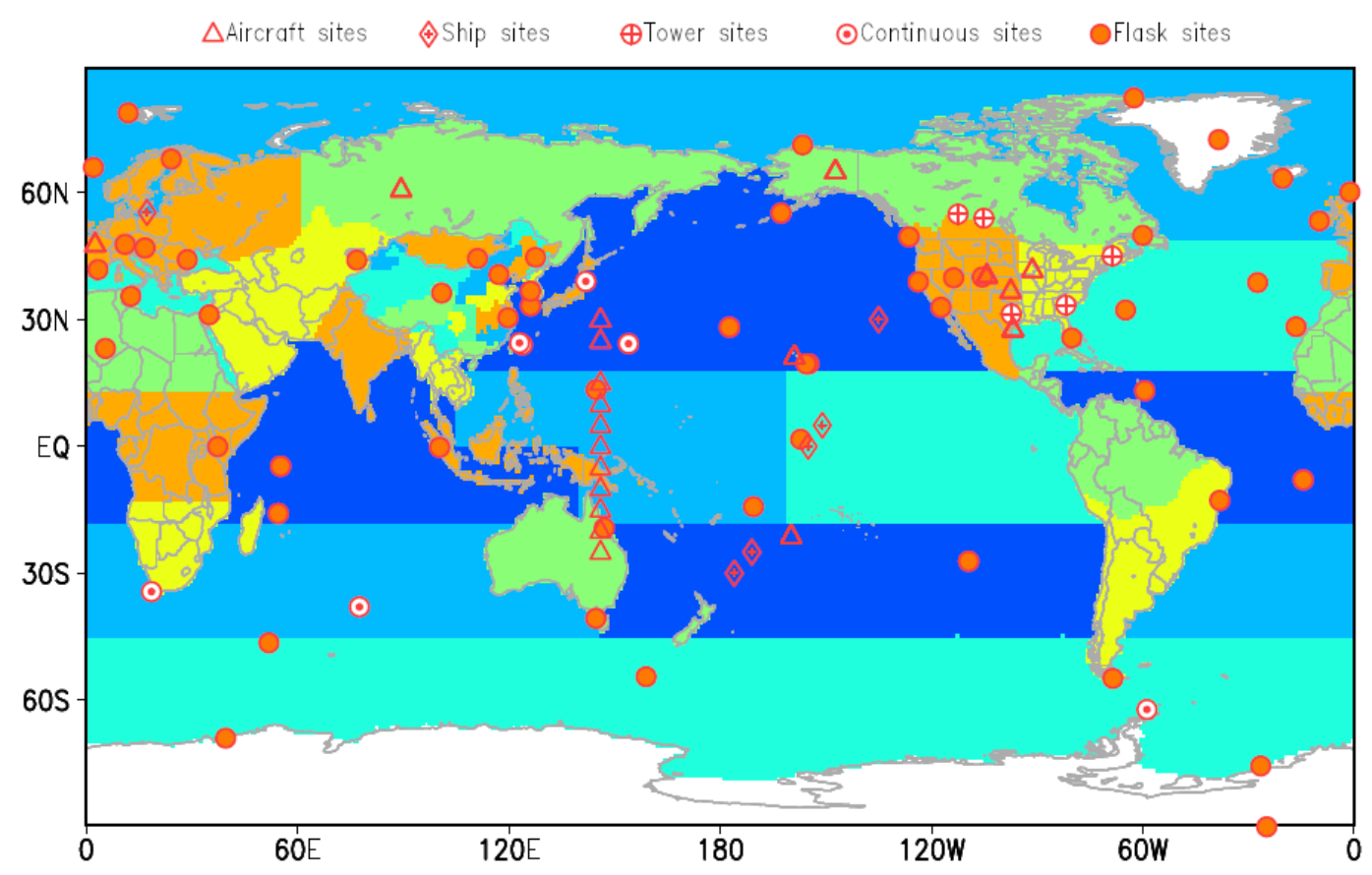

Fig. 2. An inversion scheme: 21 regions in Asia (13 regions in China) and 22 regions for the rest of the globe. Locations of $133 \mathrm{CO}_{2}$ observational sites are also indicated, including 57 flask sites, 7 continuous sites, 5 tower sites, 6 ship sites, and 58 aircraft sites.

reanalyzed data, and remotely sensed leaf area index (LAI) (Deng et al., 2006). The annual fluxes at each grid are neutralized according to the work of Deng and Chen (2011). The ocean flux is modeled using the OPA-PISCES-T model, which is a state-of-the-art combined global ocean circulation (OPA) and biogeochemistry model (PISCES-T) (Buitenhuis et al., 2006), and it has been evaluated to have good performances on ocean carbon fluxes in the equatorial Pacific (Feely et al., 2006), North Pacific (McKinley et al., 2006) and Southern Ocean (Le Quéré et al., 2007). We have evaluated the annual global ocean fluxes calculated using

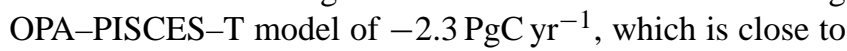
the frequently used ocean fluxes in most inversions (e.g., Maksyutov et al., 2003; Houweling et al., 2004; Chevallier et al., 2010) of Takahashi et al. (2009) $\left(-2.0 \mathrm{PgC} \mathrm{yr}^{-1}\right)$. Using the same ocean fluxes and uncertainties, Deng and Chen (2011) have successfully inverted the global land and ocean fluxes.

There are many sources of uncertainty in these model simulations, including errors in the meteorological data, errors of model parameters, and errors caused by the model structure. So, estimating the uncertainties of the simulated carbon fluxes is extremely difficult. In this study, we use an uncertainty of $2.0 \mathrm{PgC} \mathrm{yr}^{-1}$ for the global land surface (Deng and Chen, 2011), and an uncertainty of $0.88 \mathrm{PgC} \mathrm{yr}^{-1}$ for the global ocean surface (Baker et al., 2006). The uncertainty on the land is spatially distributed based on the annual NPP distribution simulated by BEPS, while the one on the ocean is distributed according to the area of each ocean region. The prior uncertainties of each region are listed in Table 1. These prior uncertainties are also in the range of those used in previous studies (e.g., Rödenbeck et al., 2003; Gurney et al., 2004; Bruhwiler et al., 2007).

\subsection{Observations and model-data mismatch errors}

$\mathrm{CO}_{2}$ observations from 133 sites are used in this study, in which 130 time series are from the GLOBALVIEW$\mathrm{CO}_{2} 2010$ dataset (GLOBALVIEW-CO ${ }_{2}, 2010$ ), including 54 flask observations, 7 continuous measurements, 5 tower sites, 6 ship sites, and 58 aircraft sites (aircraft at each flight level is considered as one site), and 3 additional China sites: Longfengshan (LFS), Shangdianzi (SDZ) and Lin'an (LAN) are obtained from Chinese Academy of Meteorological Sciences (CAMS), China Meteorological Administration (CMA). The Mt. Waliguan GAW baseline station in western China has been included in the GLOBALVIEW dataset. There are over 300 time series of observations in GLOBALVIEW-CO 2010 dataset, which were measured by many different organizations. The dataset is a product of the observations, including smoothed values, and interpolated and extrapolated values. In this study, we select data according to the following principles: (1) only smoothed values are selected; (2) if there are many stations in one region, only the data from NOAA Earth System Research Laboratory (ESRL) are selected (e.g., North America), while if only few stations in one region, the data from other organizations are also considered (e.g., Asia); (3) we generally do not choose tower 
Table 1. Prior and posterior errors as well as the error reduction rates for each region.

\begin{tabular}{|c|c|c|c|c|c|c|c|c|c|}
\hline ID & Region & $\begin{array}{l}\text { Prior error } \\
\left(\mathrm{PgC} \mathrm{yr}^{-1}\right)\end{array}$ & $\begin{array}{l}\text { Post. error } \\
\left(\mathrm{PgC} \mathrm{yr}^{-1}\right)\end{array}$ & $\begin{array}{l}\text { Error redu. } \\
\text { rate }(\%)\end{array}$ & ID & Region & $\begin{array}{l}\text { Prior error } \\
\left(\mathrm{PgC} \mathrm{yr}^{-1}\right)\end{array}$ & $\begin{array}{l}\text { Post. error } \\
\left(\mathrm{PgC} \mathrm{yr}^{-1}\right)\end{array}$ & $\begin{array}{l}\text { Error redu. } \\
\text { rate }(\%)\end{array}$ \\
\hline 1 & North Pacific & 0.28 & 0.16 & 41.2 & 29 & South China forest & 0.06 & 0.06 & 2.0 \\
\hline 2 & West Pacific & 0.20 & 0.16 & 22.3 & 30 & Southwest China forest & 0.11 & 0.11 & 3.0 \\
\hline 3 & East Pacific & 0.22 & 0.19 & 13.2 & 31 & East China forest & 0.06 & 0.05 & 11.2 \\
\hline 4 & South Pacific & 0.38 & 0.25 & 33.4 & 32 & Central China forest & 0.06 & 0.06 & 2.6 \\
\hline 5 & Northern ocean & 0.16 & 0.08 & 47.1 & 33 & Northeast China forest & 0.07 & 0.06 & 5.8 \\
\hline 6 & North Atlantic & 0.18 & 0.15 & 19.4 & 34 & North China grass & 0.08 & 0.07 & 16.4 \\
\hline 7 & Tropical Atlantic & 0.18 & 0.16 & 11.0 & 35 & West China grass & 0.12 & 0.06 & 47.2 \\
\hline 8 & South Atlantic & 0.20 & 0.18 & 9.1 & 36 & Northwest China grass & 0.02 & 0.02 & 0.8 \\
\hline 9 & Southern Ocean & 0.46 & 0.14 & 70.0 & 37 & Central China crop & 0.02 & 0.02 & 0.2 \\
\hline 10 & Tropical Indian & 0.26 & 0.20 & 21.8 & 38 & North China crop & 0.07 & 0.07 & 3.6 \\
\hline 11 & South Indian & 0.21 & 0.18 & 14.1 & 39 & Yangtze Plain crop & 0.06 & 0.06 & 11.7 \\
\hline 12 & Mediterranean & 0.05 & 0.05 & 8.7 & 40 & Northeast China crop & 0.07 & 0.06 & 21.0 \\
\hline 13 & Boreal N. America & 0.21 & 0.13 & 39.5 & 41 & West China desert & 0.02 & 0.02 & 0.4 \\
\hline 14 & Temp east America & 0.31 & 0.18 & 41.6 & & & & & \\
\hline 15 & Temp west America & 0.31 & 0.13 & 60.0 & & North America & 0.49 & 0.21 & 56.5 \\
\hline 16 & Tropical America & 1.21 & 0.62 & 48.6 & & South America & 1.42 & 0.71 & 50.0 \\
\hline 17 & Temp S. America & 0.75 & 0.54 & 27.2 & & Africa & 1.10 & 0.84 & 23.6 \\
\hline 18 & Northern Africa & 0.06 & 0.06 & 3.3 & & Europe & 0.47 & 0.17 & 63.8 \\
\hline 19 & Tropical Africa & 0.30 & 0.25 & 17.6 & & Australia & 0.25 & 0.11 & 56.0 \\
\hline 20 & Southern Africa & 1.03 & 0.60 & 42.1 & & Asia & 0.84 & 0.39 & 53.6 \\
\hline 24 & Australia & 0.25 & 0.12 & 53.8 & & China & 0.26 & 0.18 & 29.6 \\
\hline 25 & Europe & 0.47 & 0.17 & 63.9 & & Northern land & 1.04 & 0.34 & 67.3 \\
\hline 21 & Boreal Asia & 0.38 & 0.18 & 51.3 & & Tropical land & 1.27 & 0.68 & 46.5 \\
\hline 22 & West Asia & 0.12 & 0.10 & 17.9 & & Southern land & 1.29 & 0.75 & 41.9 \\
\hline 23 & Southeast Asia & 0.28 & 0.19 & 30.8 & & Global land & 2.00 & 0.63 & 68.5 \\
\hline 42 & Indo-China & 0.48 & 0.34 & 28.8 & & Northern ocean & 0.37 & 0.22 & 40.5 \\
\hline 43 & Indian peninsula & 0.40 & 0.33 & 18.8 & & Tropical ocean & 0.43 & 0.36 & 16.3 \\
\hline 26 & Mongolia & 0.07 & 0.06 & 20.6 & & Southern Ocean & 0.66 & 0.31 & 53.0 \\
\hline 27 & Korean peninsula & 0.03 & 0.03 & 6.2 & & Global ocean & 0.88 & 0.56 & 36.4 \\
\hline 28 & Japan & 0.06 & 0.05 & 13.9 & & Global total & 2.27 & 0.36 & 84.1 \\
\hline
\end{tabular}

observations unless there are very few observations in that area, and if one tower station is selected, only the top-level observations are used; and (4) stations near large cities or airports are mostly not used. For the continuous sites and two tower sites located in the US (ESRL, Fig. 2), the data observed during 12:00-16:00 LST are used, and for another three tower sites located in Canada (Environment Canada), the measurements between 15:00 and 17:00 LST are used. LFS, SDZ and LAN are three regional background stations established by CMA/CAMS, which are located in Northeast China, North China, and East China, respectively. The measurements of these stations were sampled and analyzed using the recommended methods of WMO/GAW, and the results are comparable with those of NOAA/ESRL. For more detailed information about these observations, please refer to Liu et al. (2009). Before monthly averaging, the weekly measurements are smoothed using the same technique as GLOBALVIEW-CO ${ }_{2}$ dataset (Masarie and Tans, 1995), and Fig. 1 shows the weekly measurements and smoothed curve in LFS. The locations of the all sites are shown in Fig. 2.

The estimation of the model-data mismatch is very difficult (Bruhwiler et al., 2007), since the errors come from both the observations (instrument errors) and the simulations. Various methods (e.g., Rayner et al., 1999a; Gurney et al., 2004; Michalak et al., 2005) have been used to determine the model-data mismatch. In this study, the data-mismatch er- ror is defined using the following function, which is similar to Peters et al. (2005) and Deng and Chen (2011).

$R=\sigma_{\text {const }}^{2}+G V s d^{2}$,

where GVsd reflects the observation error, which is the standard deviation of the residual distribution in the average monthly variability (var) file of GLOBALVIEW- $\mathrm{CO}_{2} 2010$, and the constant portion $\sigma_{\text {const }}$ reflects the simulation error, due to the different performances of the model on each observation station. This portion also varies with station. Except for some difficult stations, the observation sites are divided into 5 categories. The categories and respective value are as follows: Antarctic sites/oceanic flask and continuous sites (0.30), ship and tower sites (1.0), mountain sites (1.5), aircraft samples (0.5), and land flask/continuous sites (0.75). The value of 3.5 is used for the difficult sites (e.g., abp_01D0, bkt_01D0). In addition, it is noted that SDZ and LAN are treated as difficult sites in this study, because SDZ is near Beijing, and LAN is near Yangtze River delta.

\section{Results and discussion}

\subsection{Uncertainty reduction}

The posterior flux uncertainties could be estimated based on formula Eq. (3) in Sect. 2. Table 1 shows the uncertainties 


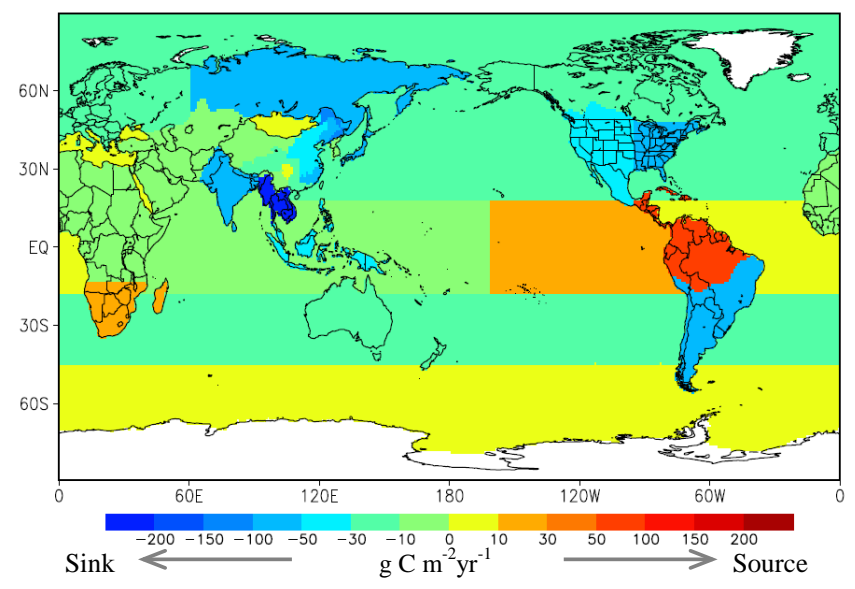

Fig. 3. Inverted mean distribution of terrestrial and ocean carbon fluxes (averaged for 2002-2008).

of prior and posterior fluxes as well as the uncertainty reduction rates of each region. For the global total, $84 \%$ of the prior flux uncertainty is reduced due to the constraint of the observations around the world. However, due to the uneven distribution of the observation sites, there are significant differences between different regions. For global land and ocean, the error reduction rates are $68.5 \%$ and $36.4 \%$, respectively, since there are many more observation sites distributed over land than over ocean, especially for the surface observation sites ( 45 vs. 30 ). Over land, the uncertainties in northern land are reduced much more than those in tropical and southern land, with largest reduction rates happening in Europe $(63.8 \%)$ and North America $(56.5 \%)$. Due to lack of enough observations in China, most China regions are with low reduction rates $(<10 \%)$, especially for South and Southwest China. Overall, $29.6 \%$ of prior flux uncertainty is reduced in China, which is relatively lower compared to North America and Europe.

\subsection{Inverted global carbon fluxes}

\subsubsection{Distribution of the carbon sinks}

In this study, the inversions are conducted from 2000 to 2009. The first two years are considered as a spin-up period, and the last year is treated as a spin-down time. Hence, the inverted results from 2002 to 2008 are used for analysis. Figure 3 shows the inverted mean distribution of terrestrial (excluding biomass burning emissions, same as thereafter) and ocean carbon fluxes for 2002-2008. Most of the land regions are inverted as carbon sinks, with strong sinks occurring in boreal Asia, South and Southeast Asia, eastern America and southern South America, while tropical America and southern Africa are carbon sources to the atmosphere. This spatial pattern is quite consistent with the MODIS global NPP changes from 2000 through 2009 (Zhao and Running, 2010), especially in Africa, North America and Eurasia. However,

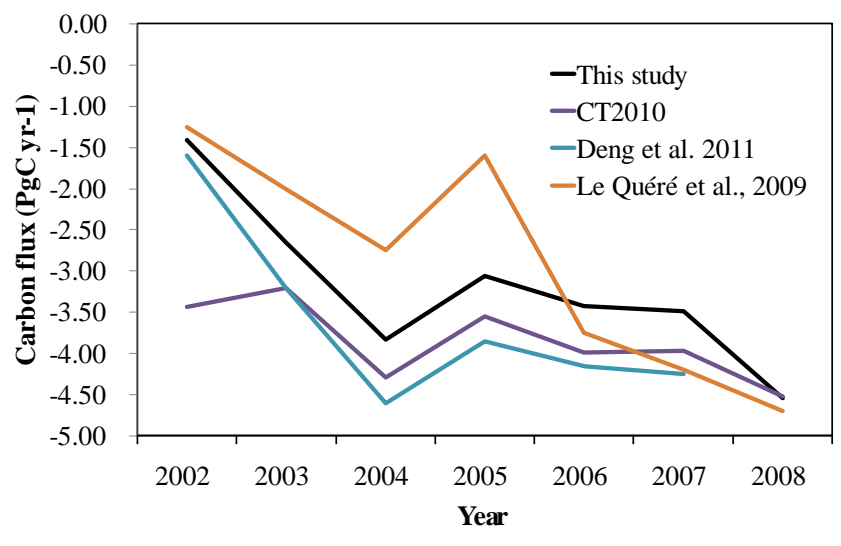

Fig. 4. Inter-annual variation of global terrestrial ecosystem carbon sinks (2002-2008).

the flux patterns in southern South America and Southeast Asia are inconsistent with the changes in MODIS NPP, and indicate that there may be large uncertainties that existed in these regions. As shown in Table 1, the posterior flux uncertainties of these two regions are 0.54 and $0.19 \mathrm{PgC} \mathrm{yr}^{-1}$, with error reduction rates of $27 \%$ and $31 \%$, respectively. In North America, our result $\left(-0.81 \pm 0.21 \mathrm{PgC} \mathrm{yr}^{-1}\right)$ is in the range of Carbon Tracker $2010\left(\mathrm{CT} 2010,-0.66 \mathrm{PgC} \mathrm{yr}^{-1}\right.$, data downloaded from http://carbontracker.noaa.gov, same as thereafter) and Deng and Chen (2001) $\left(-0.89 \mathrm{PgC} \mathrm{yr}^{-1}\right)$. In Europe, our result $\left(-0.28 \pm 0.17 \mathrm{PgC} \mathrm{yr}^{-1}\right)$ is close to CT2010 ( $\left.-0.31 \mathrm{PgC} \mathrm{yr}^{-1}\right)$, but higher than CarbonTrackerEurope $\left(-0.165 \mathrm{PgC} \mathrm{yr}^{-1}\right.$, Peters et al., 2010) and Deng and Chen (2011) $\left(-0.22 \mathrm{PgC} \mathrm{yr}^{-1}\right)$. In South Asia, the inverted result is $-0.30 \pm 0.33 \mathrm{PgC} \mathrm{yr}^{-1}$, which is higher than the results obtained based on bottomup methods $\left(-0.19 \pm 0.19 \mathrm{PgC} \mathrm{yr}^{-1}\right.$, Patra et al., 2013). The estimated global terrestrial ecosystem carbon sink is $-3.20 \pm 0.63 \mathrm{PgC} \mathrm{yr}^{-1}$ (Table 2), which is slightly lower than the results of Deng and Chen (2011) $\left(-3.63 \pm 0.49 \mathrm{PgC} \mathrm{yr}^{-1}\right)$ and CT2010 (-3.85 $\left.\mathrm{PgC} \mathrm{yr}^{-1}\right)$, but close to the value estimated by Le Quéré et al. (2009) (2000-2008, $\left.-3.0 \pm 0.9 \mathrm{PgC} \mathrm{yr}^{-1}\right)$ using five global vegetation models.

\subsubsection{Inter-annual variations}

Figure 4 shows the inter-annual variation (IAV) of the inverted global land carbon sinks. For comparison, the IAVs from CT2010, Deng and Chen (2011) and Le Quéré et al. (2009) are also shown. The global IAV of land sinks is $3.13 \mathrm{PgC} \mathrm{yr}^{-1}$, with a range from $-1.41 \mathrm{PgC} \mathrm{yr}^{-1}$ to $-4.54{\mathrm{PgC} \mathrm{yr}^{-1}}^{-1}$. From 2002 to 2008 , the global terrestrial carbon sink has an increasing trend. It increases from 2002 to 2004 , and decreases in 2005 , then continuing to increase from 2005 to 2008. The land carbon sink is the lowest in 2002 and highest in 2008. The IAVs of the land sinks show remarkable correlation with the El Niño Southern Oscillation 
Table 2. Comparison of the inverted carbon sinks in this study with previous studies during 2002-2008 $\left(\mathrm{PgC} \mathrm{yr}^{-1}\right)$.

\begin{tabular}{lrrrrrr}
\hline Region & Global & Land & Ocean & $\begin{array}{r}\text { North } \\
\text { America }\end{array}$ & Europe & China \\
& & & & $-0.81 \pm 0.21$ & $-0.28 \pm 0.17$ & $-0.28 \pm 0.18$ \\
\hline This study & $-5.75 \pm 0.39$ & $-3.20 \pm 0.63$ & $-2.55 \pm 0.56$ & -0.81 & - \\
Deng and Chen, 2011 & -5.58 & $-3.63 \pm 0.49$ & $-1.95 \pm 0.41$ & $-0.89 \pm 0.18$ & -0.22 & -0.26 \\
CarbonTracker 2010 & -5.72 & -3.85 & -1.87 & -0.66 & -0.31 & - \\
Le Quéré et al., 2009 & -5.3 & $-3.0 \pm 0.9$ & $-2.3 \pm 0.4$ & - & - \\
\hline
\end{tabular}

${ }^{\mathrm{a}}$ Mean from 2002 to 2007 ; $^{\mathrm{b}}$ mean from 2000 to 2008.

(ENSO); the weaker land sinks in 2002, 2005, and 2007 correspond to the strong El Niño events in 2002-2003, 2004-2005, and 2006-2007, respectively, while the stronger land sink in 2008 corresponds to the La Niña event (http:// www.esrl.noaa.gov/psd/enso/mei/). That is because the IAVs are dominated by the tropical land fluxes in this study, and the IAVs of tropical land fluxes have been studied to have strong relationship with the ENSO cycle (Rayner et al., 1999b; Rödenbeck, et al., 2003; Patra et al., 2005b; Gurney et al., 2012).

The increasing trend in the terrestrial sink in this study agrees well with the other studies (Fig. 4). During 20022008, our results are weaker than Deng and Chen (2011) and CT2010, which are caused by the partition of carbon sinks between land and ocean, since the carbon sink of ocean $\left(-2.55 \pm 0.56 \mathrm{PgC} \mathrm{yr}^{-1}\right)$ inverted in this study is larger than that $\left(\sim-1.9 \mathrm{Pg} \mathrm{C} \mathrm{yr}^{-1}\right)$ obtained by Deng and Chen (2011) and CT2010. The differences between this study and Deng and Chen (2011) are mainly due to the selection in observation sites, as the selection of $\mathrm{CO}_{2}$ data in this study is much stricter than Deng's work. Many more $\mathrm{CO}_{2}$ data were used in Deng and Chen (2011), especially over continental region. The differences with CT2010 may be related to the inversion approach, the observations and the prior fluxes, as CT2010 uses the method of ensemble Kalman filter, the observations at the sampling time, and CASA model outputs and Takahashi ocean fluxes (Takahashi et al., 2009) as prior fluxes. Le Quéré et al. (2009) showed the land sinks of global land carbon sinks estimated using five global vegetation models. During 2002-2005, our results show stronger IAVs than those of Le Quéré et al. (2009), while after 2006, our results are lower than those of Le Quéré et al. (2009). Figure 5 shows a further comparison with previous inversion studies (Chevallier et al., 2010; Rödenbeck, 2005; Peters et al., 2007; Deng and Chen, 2011) as well as Le Quéré et al. (2009) focusing on global net carbon fluxes (Fig. 5a) and terrestrial ecosystem carbon fluxes (land sinks + biomass burning emissions) (Fig. 5b). The global net carbon exchange shows considerable agreement. Our result is in the range of previous studies. However, the ecosystem fluxes inverted in this study are weaker than the previous inversion studies for all the years, but close to Le Quéré et al. (2009) during 2002-2005. These
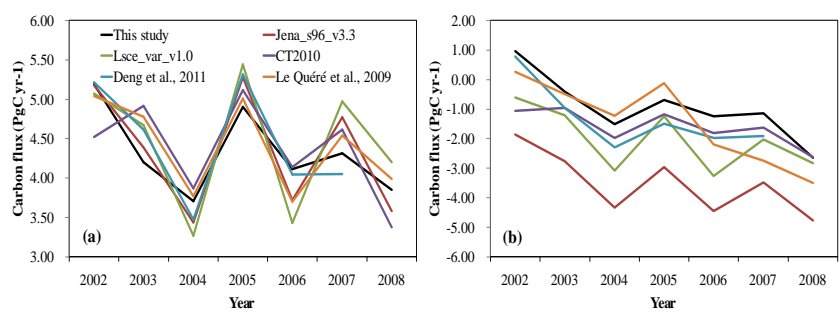

Fig. 5. Inter-annual variation of global carbon fluxes (a, global net carbon fluxes; b, terrestrial ecosystem carbon fluxes, land sinks + biomass burning); for details of the inversion systems of Lsce_var_v1.0, Jena_s96_v3.3 and CT2010, please refer to Chevallier et al. (2010), Rödenbeck (2005), and Peters et al. (2007), respectively.

indicate that the land sink may be a little underestimated and the ocean sink may be overestimated in this study.

\subsection{Inverted China carbon fluxes}

\subsubsection{Distribution of the carbon sinks}

As shown in Fig. 3, most China areas appear to be carbon sinks, with strongest carbon sinks located in Northeast China (greater than $-50 \mathrm{gC} \mathrm{m}^{-2} \mathrm{yr}^{-1}$ ). Large carbon sinks (greater than $-30 \mathrm{gC} \mathrm{m}^{-2} \mathrm{yr}^{-1}$ ) also occur in the North China crop region, Southeast China forest region and Southwest China grass region. South and Southwest China are inverted to be weak sinks or sources. During 2002-2008, the inverted mean carbon sink in China is $-0.28 \pm 0.18 \mathrm{PgC} \mathrm{yr}^{-1}$, in which $36 \%$ of the carbon is absorbed in Northeast China (including region 33 and 40 ), $30 \%$ of the carbon is captured in North and Northwest China grass regions (including region 34 and 35), and $24 \%$ of the uptake is located in eastern China (including region 31, 38 and 39). The carbon sink in China derived in this study is very close to that in Europe $\left(-0.28 \pm 0.17 \mathrm{PgC} \mathrm{yr}^{-1}\right)$. Basically, this spatial pattern agrees well with the NPP changes derived by Zhao and Running (2010). Compared with previous studies, the inverted carbon sinks in this study are close to the result of CT2010 $\left(-0.26 \mathrm{PgC} \mathrm{yr}^{-1}\right)$ for the same period, but lower than the inversion ensemble result $\left(-0.35 \pm 0.33 \mathrm{PgC} \mathrm{yr}^{-1}\right)$ over the period of 1996-2005, which is derived by Piao 


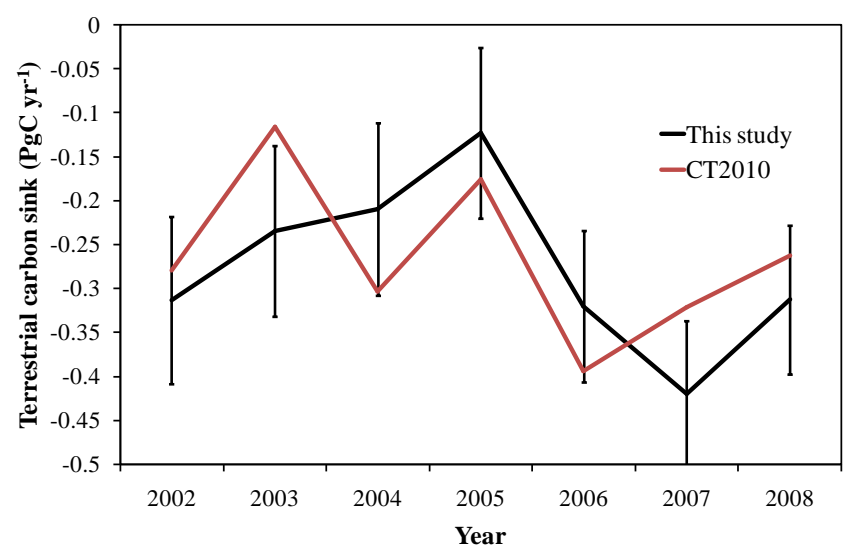

Fig. 6. Inter-annual variation of the terrestrial ecosystem carbon sinks in China (2002-2008).

et al. (2009). When we distinguish different ecosystem regions, the forest, grass, and crop regions capture carbon of $-0.097 \pm 0.16 \mathrm{PgC} \mathrm{yr}^{-1}(35 \%),-0.084 \pm 0.09 \mathrm{PgC} \mathrm{yr}^{-1}$ $(30 \%)$ and $-0.093 \pm 0.11 \mathrm{PgC} \mathrm{yr}^{-1}(34 \%)$, respectively. The inverted carbon sinks of forest and grass regions are comparable with Carbon Tracker's results, while the carbon sink in crop regions is stronger than CT2010, which may be attributed to the three China observation stations added in this study, since these three sites are located in or close to crop regions.

\subsubsection{Inter-annual variations}

Figure 6 shows the IAVs of the carbon sinks of terrestrial ecosystems in China. The IAV of China land sinks is $0.30 \mathrm{PgC} \mathrm{yr}^{-1}$, with a range from $-0.12 \mathrm{PgC} \mathrm{yr}^{-1}$ to $-0.42 \mathrm{PgC} \mathrm{yr}^{-1}$. From 2002 to 2005 , the carbon sink decreases year by year, and then there is an increasing trend. During 2002 to 2008, the carbon sink is lowest in 2005, and highest in 2007. Overall, there is an increasing trend for the land sinks in China. For comparison, the IAVs of land sinks in China inverted by CT2010 are also shown in Fig. 6. The IAVs of CT2010 also show an increasing trend. However, it could be found that the IAVs between this study and CT2010 are different: in 2003, there is a lowest land sink in CT2010, while the land sink estimated in this study is moderate; in 2004, the land sink of CT2010 is much stronger than that in 2003, while in this study it is slightly weaker than that in 2003; in CT2010, the highest land sink occurs in 2006, while in this study, the highest occurs in 2007. Temperature, precipitation and solar radiation are three key climate factors that impact the photosynthesis of plants. Generally, high temperature, plenty of rainfall and solar radiation are beneficial to plant growth and result in stronger carbon sinks. Figure 7 shows the anomalies of land sinks and the anomalous percentages of the three climate factors during 2002-2008 in China. Monthly climate data of 658 stations in China dur- ing the study period are used for analysis, which were obtained from China Meteorological Administration (CMA). In 2002, there are positive anomalies of all three climate factors, especially for annual precipitation (greater than $8 \%$ ), corresponding to the negative anomaly of land sink in this study (increasing sink). In 2003, the anomalies of all three factors are negative, corresponding to the decrease of land sink. In 2004, though the solar radiation increases (3.5\%), the annual precipitation is the least, with an anomalous percentage of more than $-5 \%$. Because of the reduced precipitation, drought was relatively severe in this year (Zou et al., 2010), corresponding to the further decrease of land sink. In 2005, the precipitation is close to normal years (anomalous percentage less than $2 \%$ ), but both solar radiation and temperature are lower than normal. Inspecting the spatial pattern for the anomalies of carbon sinks and annual mean temperature (Fig. 8a, b), we found that in 2005 the temperature decreases in most of the China region, with highest negative anomalous percentage occurring in Northeast China (greater than $10 \%$ ), and the land sinks decrease over the whole China region, with a significant decrease happening in Northeast China. In 2006, the temperature rises significantly from 2005 to be close to normal years, while the precipitation decreases $(-2.5 \%)$, leading to severe drought in this year (Zou, et al., 2010), corresponding to a moderate land sink in this year. In 2007, the temperature is highest during this study period, with anomalous percentage greater than $5 \%$, and the solar radiation and rainfall are close to normal years, corresponding to the strongest land sink. Figure $8 \mathrm{c}$ and $\mathrm{d}$ show the spatial pattern for the anomalies of the carbon sinks and annual mean temperature in this year. It could be found that the temperature significantly increases in Northeast and eastern China region, correspondingly, and the land sinks increase in these regions. In 2008, the temperature and solar radiation are close to normal years, while the rainfall is more adequate than normal years, with anomalous percentage higher than $6 \%$. The climate factors in this year are similar to those in 2002; correspondingly, the land sink is also close to 2002. These indicate that the inverted IAVs of this study could be reasonably explained with variations in climate factors. In addition, since the prior land sinks are neutral in this study, these IAVs are fully constrained by the observations, indicating that the inversion is effective in this study.

The IAVs in China are not the same as those for the globe (Sect. 3.2.2). The main reason may be that the IAVs of global carbon sinks are dominated by tropical land fluxes, which are highly affected by ENSO (Sect. 3.2.2), but the impacts of ENSO on tropical zone and on China are different. Except in 2005, it seems that the IAVs of China land sinks have negative correlation with ENSO cycle: the increases of land sinks correspond to strong El Niño events, while the decrease of land sink corresponds to La Niña event. A similar relationship also found in temperate North America (Patra et al., 2005b). North Atlantic Oscillation (NAO) is another climate event impacting the global and regional climate. Patra 


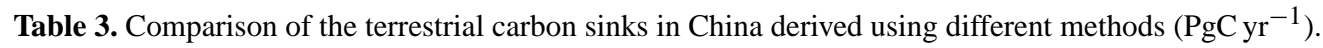

\begin{tabular}{|c|c|c|c|c|c|c|}
\hline Reference & Method & Period & Forest & Grass & Crop & Total \\
\hline This study & $\begin{array}{l}\text { Inversion } \\
\text { method }\end{array}$ & 2002-2008 & $-0.097 \pm 0.16$ & $-0.084 \pm 0.09$ & $-0.093 \pm 0.11$ & $-0.28 \pm 0.18$ \\
\hline This study ${ }^{\mathrm{a}}$ & & 2002-2008 & -0.116 & -0.084 & -0.105 & -0.31 \\
\hline $\begin{array}{l}\text { CarbonTracker } \\
2010\end{array}$ & $\begin{array}{l}\text { Assimilation } \\
\text { system }\end{array}$ & 2002-2008 & -0.10 & -0.08 & -0.08 & -0.26 \\
\hline $\begin{array}{l}\text { Tian et } \\
\text { al. }(2011)^{b}\end{array}$ & $\begin{array}{l}\text { Process-based } \\
\text { model }\end{array}$ & 1961-2005 & -0.115 & -0.045 & -0.049 & $-0.21 \pm 0.078$ \\
\hline \multirow[t]{3}{*}{$\begin{array}{l}\text { Piao } \\
\text { et al. }(2009)^{\text {b }}\end{array}$} & $\begin{array}{l}\text { Inventory-based } \\
\text { method }\end{array}$ & 1982-1999 & -0.101 & -0.037 & -0.033 & $-0.18 \pm 0.073$ \\
\hline & $\begin{array}{l}\text { Process-based } \\
\text { model }\end{array}$ & 1980-2002 & - & - & - & $-0.17 \pm 0.073$ \\
\hline & Inversion study & 1996-2005 & - & - & - & $-0.35 \pm 0.33$ \\
\hline Pan et al. (2011) & $\begin{array}{l}\text { Inventory-based } \\
\text { method }\end{array}$ & 2000-2007 & -0.115 & - & - & - \\
\hline
\end{tabular}

a The results after considering the carbon emissions in the form of reactive biogenic volatile organic compounds (BVOCs) and from the import of wood and food.

b The carbon sinks of shrubland have been distributed to forest, grass and crop land according to the fractions of $36.8 \%, 38.8 \%$, and $11.7 \%$, respectively, since the shrubland in this study is included in the forest, grass and crop regions.

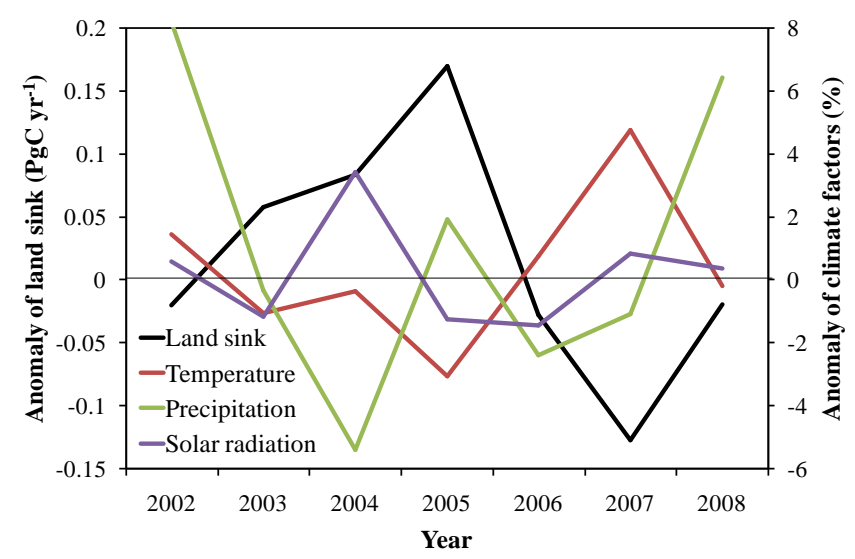

Fig. 7. Inter-annual variations of the anomaly of terrestrial carbon sinks and anomalous percentages of climate factors in China (2002-2008).

et al. (2005b) found that the anomalies of the carbon fluxes in temperate North America also have a strong relationship with the NAO cycle. Hence, we examine the relationship between the IAVs of China land sinks and NAO cycle as well. Comparing to the JFM (January-February-March) season standardized NAO index reported on the website of Climate Prediction Center (http://www.cpc.ncep.noaa.gov), we find that the IAVs of China land sinks also have a significant relationship with the NAO cycle: the strong land sinks in 2002 and 2007 correspond to the remarkably positive NAO index in 2002 and 2007, while the lowest land sink in 2005 corresponds to the negative NAO index in that year. Generally, ENSO and NAO events may result in a warmer winter in China (Chen et al., 2012; Wu and Huang, 1999), which may lengthen the growing seasons, causing much stronger carbon sinks.

\subsubsection{Carbon budget in China}

The inverted net carbon flux during 2002-2008 is 1.37 $\mathrm{PgC} \mathrm{yr}^{-1}$ in China, with fossil fuel and biomass burning emissions of 1.64 and $0.014 \mathrm{PgC} \mathrm{yr}^{-1}$, and terrestrial land sink of $-0.28 \pm 0.18{\mathrm{PgC} \mathrm{yr}^{-1}}^{-}$. However, another two carbon sources were not considered in this inversion study. First, carbon could be emitted from the consumption of wood and food imported from outside of China. Based on Food and Agriculture Organization of the United Nations (FAO) statistical databases, Piao et al. (2009) estimated that $0.008 \mathrm{PgC}$ of wood and $0.004 \mathrm{PgC}$ of food were imported into China every year. Second, Terrestrial ecosystems also emit carbon in the form of biogenic volatile organic compounds (BVOCs), and most of these BVOCs are oxidized to $\mathrm{CO}$ in the atmosphere (Naik et al., 2004), and then converted to $\mathrm{CO}_{2}$ after reacting with $\mathrm{OH}$. Guenther (2002) noted that the predicted annual global reactive BVOC emissions of about $1.2 \mathrm{PgC}$ could result in the annual production of approximately $1.0 \mathrm{PgC}$ as $\mathrm{CO}_{2}$ per year $(83 \%)$. Granier et al. (2000) estimated that about $80 \%$ of the reactive dominant BVOC (i.e., isoprene) got oxidized to $\mathrm{CO}_{2}$. Hence, BVOCs play an important role in the global carbon budget and cycling. Most reactive BVOCs have a short lifetime in the atmosphere $(<1$ day), but the conversion from $\mathrm{CO}$ to $\mathrm{CO}_{2}$ is slow and usually takes 1-2 months. Hence, the observations of $\mathrm{CO}_{2}$ concentration in or around China have already included the contributions from the atmospheric oxidization of reactive BVOCs emitted around the globe. Therefore, without considering the full chemistry, we treat this indirect $\mathrm{CO}_{2}$ source implicitly from $\mathrm{BVOC}$ oxidation as the direct source of $\mathrm{CO}_{2}$ from the 

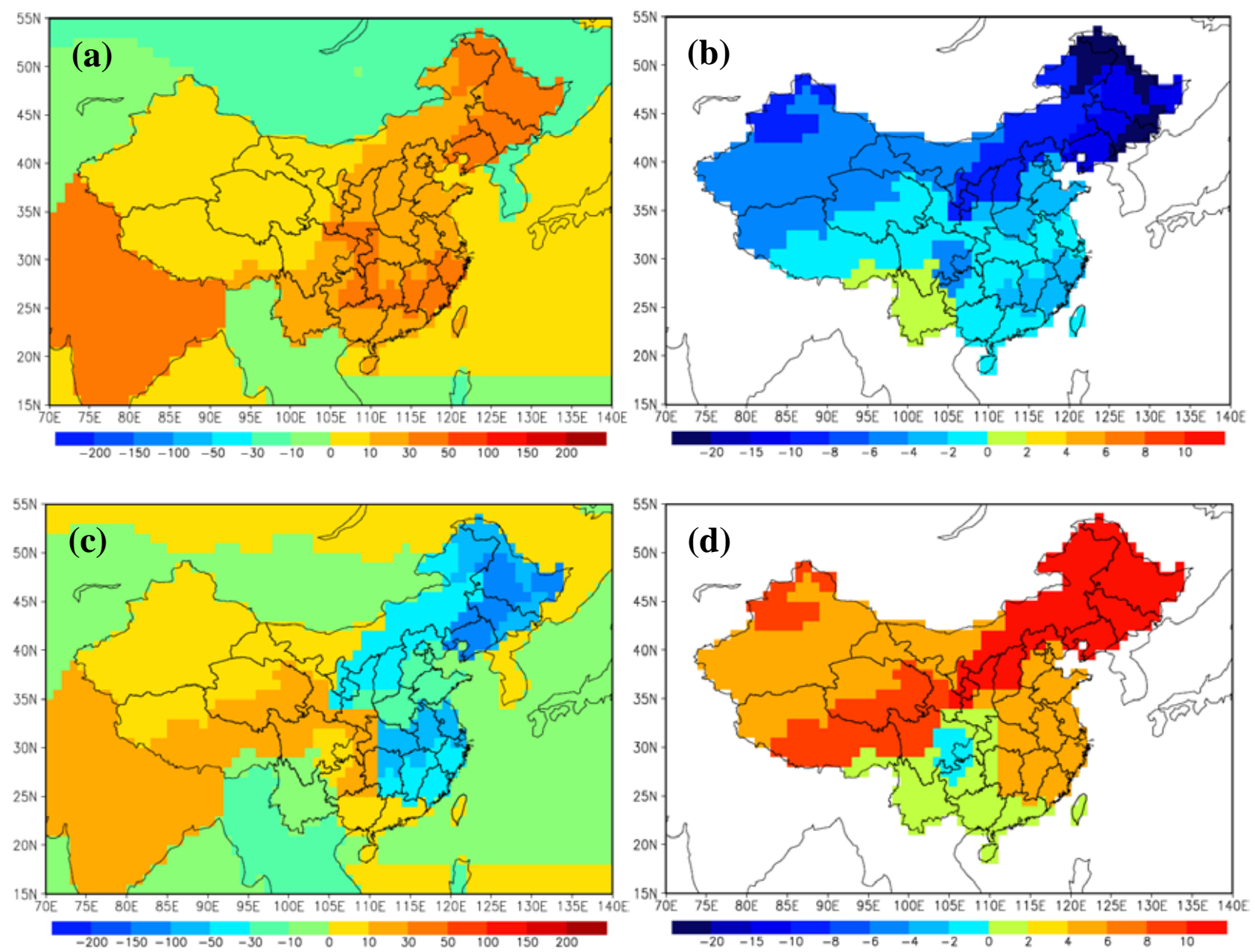

Fig. 8. Anomaly of land sinks (a, $\mathbf{c}, \mathrm{gC} \mathrm{m}^{-2} \mathrm{yr}^{-1}$, positive indicates sink decreases; negative indicates sink increases) and anomalous percentage of annual mean temperature (b, d, \%, positive indicates temperature increases; negative indicates temperature decreases) in 2005 (a and b) and 2007 (c and d).

biosphere and hence overestimate the direct $\mathrm{CO}_{2}$ source from the biosphere or underestimate the biospheric $\mathrm{CO}_{2}$ sink. Because of the slow conversion from BVOCs to $\mathrm{CO}_{2}$ in the well-mixed atmosphere, we expect small regional differences in $\mathrm{CO}_{2}$ from the contributions of BVOCs. In our global-scale inversion, $\mathrm{CO}_{2}$ observations around the globe are used, and regional biases in the inverted net $\mathrm{CO}_{2}$ flux due to $\mathrm{BVOC}-$ $\mathrm{CO}-\mathrm{CO}_{2}$ conversions are expected to be similar to those in other regions of the globe. As China's land area is about $2 \%$ of the global surface area, we estimate that our inversion without considering the full chemistry underestimates the $\mathrm{CO}_{2}$ sink in China by $0.02 \mathrm{PgC} \mathrm{yr}^{-1}$ (i.e., $2 \%$ of the global value of $1.0 \mathrm{PgC} \mathrm{yr}^{-1}$ ), which is also close to the value estimated from the emissions of reactive BVOCs (i.e., isoprene and monoterpene, $24 \mathrm{TgC} \mathrm{yr}^{-1}$, Jiang et al., 2012) in China $\left(24 \mathrm{TgC} \mathrm{yr}^{-1} \times 80 \%=0.019 \mathrm{PgC} \mathrm{yr}^{-1}\right)$. Though this underestimation is very small, it may be important when we compare the inversion result with the process model results. Hence, we further estimate that China land $\mathrm{CO}_{2}$ sink is about $-0.28+(-0.012)+(-0.02)=-0.31 \mathrm{PgC} \mathrm{yr}^{-1}$ (Fig. 9), which offsets $19 \%$ of the fossil fuel carbon emissions. This result is higher than the previous results obtained through process-based modeling (Tian et al., 2011; Piao et al, 2009) and inventories-based estimation (Piao et al., 2009) (Table 3).

Most reactive BVOCs are emitted from forest area (Jiang et al., 2012), while most imported food and wood are probably consumed in crop regions. Therefore, we estimate that the carbon sinks of forest, grass, and crop region are -0.116 , -0.084 , and $-0.105 \mathrm{PgC} \mathrm{yr}^{-1}$, respectively. Compared with previous studies, the carbon sink of forest land is comparable with the values of Tian et al. (2011), Piao et al. (2009) and Pan et al., (2011), while the carbon sinks of grassland and cropland are slightly stronger than the results of Tian et al. (2011) and Piao et al. (2009), and the reason may be attributed to the fact that the grass and crop regions in this 


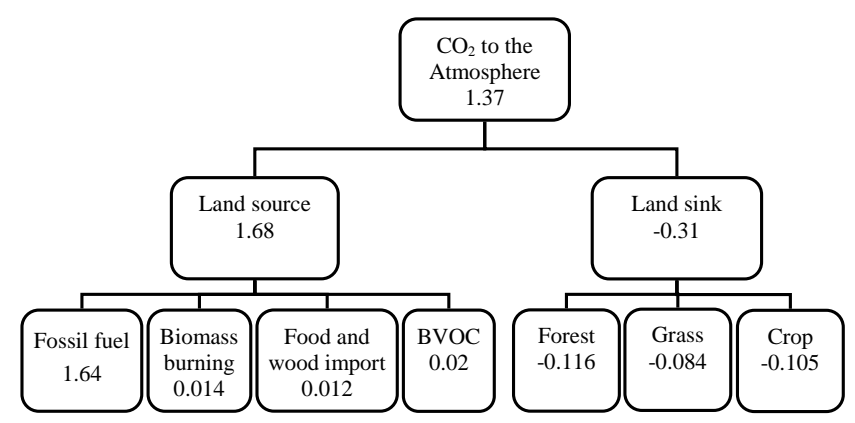

Fig. 9. Carbon budget in China $\left(\mathrm{PgC} \mathrm{yr}^{-1}\right)$.

study include some forest covers. If we consider the contribution of small forests in grass and crop regions, the forest carbon sinks estimated in this study would be larger than the results of previous studies. Nevertheless, the estimations of the carbon sinks from different ecosystems are very rough, and in order to derive more accurate carbon sinks for different ecosystems, more detailed regional partition schemes and more $\mathrm{CO}_{2}$ measurements in China are needed.

\section{Summary and conclusions}

A nested atmospheric inversion system with focus on China using the Bayesian approach is established in this study. The global surface is separated into 43 regions based on the 22 TransCom large regions, with 13 small regions in China. Monthly $\mathrm{CO}_{2}$ concentrations from 130 GlobalView sites (Mt. Waliguan GAW baseline station in western China included) and the extra 3 China sites are used in this system. The TM5 model is used for calculating the monthly transport matrix, which is run in a horizontal resolution of $3^{\circ} \times 2^{\circ}$. The carbon fluxes of terrestrial ecosystems and the air-water interface are considered as prior fluxes, which are simulated using the BEPS model and the OPA-PISCES-T model, respectively.

Using this inversion system, we investigate the spatial and temporal characteristics of the global and China terrestrial ecosystem carbon fluxes during 2002-2008. The inverted global terrestrial carbon sinks mainly occur in boreal Asia, South and Southeast Asia, eastern US and southern South America. Most China areas appear to be carbon sinks, with strongest carbon sinks located in Northeast China. From 2002 to 2008, the global terrestrial carbon sink has an increasing trend, with the lowest carbon sink in 2002. The land carbon sinks in China also display an increasing trend, with lowest sink in 2005 and highest sink in 2007. The interannual variations (IAVs) of the global land sinks show remarkable correlation with the El Niño Southern Oscillation (ENSO), while the IAVs in China show a strong relationship with temperature and precipitation. The mean global and China terrestrial carbon sinks over the period 2002-2008 are $-3.20 \pm 0.63$ and $-0.28 \pm 0.18 \mathrm{PgC} \mathrm{yr}^{-1}$, respectively. Considering the emissions of biogenic volatile organic compounds (BVOCs) and the import of wood and food, we estimate that the China terrestrial ecosystem carbon sink is about $-0.31 \mathrm{PgC} \mathrm{yr}^{-1}$ during 2002-2008.

Though large uncertainties still exist in this study, the uncertainty reduction in the Asian region is relatively low compared to Europe and North America, especially in South and Southwest China because of the lower density of $\mathrm{CO}_{2}$ observation sites in Asia. In order to improve the inversion further, more $\mathrm{CO}_{2}$ observations over these regions are needed. This study first gives the insight into the inter-annual variations of the terrestrial carbon sinks in China from the atmospheric perspective, which is helpful for understanding mechanisms influencing the regional carbon cycle.

Acknowledgements. This work was supported by the National Key Basic Research Development Program of China (Grant No. 2010CB950704, 2010CB950601 and 2010CB833503), National Natural Science Foundation of China (Grant No. 41201194 and 41175116), and the Priority Academic Development Program of Jiangsu Higher Education Institutions. The authors also wish to thank Feng Deng at the University of Toronto in Canada for his valuable help.

Edited by: X. Wang

\section{References}

Baker, D. F., Law, R. M., Gurney, K. R., Rayner, P., Peylin, P., Denning, A.S., Bousquet, P., Bruhwiler, L., Chen, Y.H., Ciais, P., Fung, I.Y., Heimann, M., John, J., Maki, T., Maksyutov, S., Masarie, K., Prather, M., Pak, B., Taguchi, S., and Zhu, Z.: TransCom 3 inversion intercomparison: Impact of transport model errors on the interannual variability of regional $\mathrm{CO}_{2}$ fluxes, 1988-2003. Global Biogeochem. Cy., 20, GB1002, doi:10.1029/2004GB002439, 2006.

Boden, T. A., Marland, G., and Andres, R. J.: Global, Regional, and National Fossil-Fuel CO2 Emissions. Carbon Dioxide Information Analysis Center, Oak Ridge National Laboratory, U.S. Department of Energy, Oak Ridge, Tenn., USA doi:10.3334/CDIAC/00001_V2010, available at: http://cdiac. ornl.gov, 2010.

Bruhwiler, L. M. P., Michalak, A. M., and Tans, P. P.: Spatial and temporal resolution of carbon flux estimates for 1983-2002, Biogeosciences, 8, 1309-1331, doi:10.5194/bg-8-1309-2011, 2011.

Buitenhuis, E., Le Quéré, C., Aumont, O., Beaugrand, G., Bunker, A., Hirst, A., Ikeda, T., O'Brien, T., Piontkovski, S., and Straile, D.: Biogeochemical fluxes through mesozooplankton, Global Biogeochem. Cy., 20, GB2003, doi:10.1029/2005GB002511, 2006.

Chen, J. M., Liu, J., Cihlar, J., and Goulden, M. L.: Daily canopy photosynthesis model through temporal and spatial scaling for remote sensing applications, Ecol. Modell., 124, 99-119, 1999.

Chen, Y. L., Zhao, Y. P., Feng, J. Q., and Wang, F.: ENSO cycle and climate anomaly in China, Chinese, J. Oceanol. Limnol., 30, 985-1000, 2012. 
Chevallier, F., Ciais, P., Conway, T. J., Aalto, T., Anderson, B. E., Bousquet, P., Brunke, E. G., Ciattaglia, L., Esaki, Y., Frohlich, M., Gomez, A. J., Gomez-Pelaez, A. J., Haszpra, L., Krummel, P., Langenfelds, R., Leuenberger, M., Machida, T., Maignan, F., Matsueda, H., Morgui, J. A., Mukai, H., Nakazawa, T., Peylin, P., Ramonet, M., Rivier, L., Sawa, Y., Schmidt, M., Steele, P., Vay, S. A., Vermeulen, A. T., Wofsy, S., and Worthy, D.: $\mathrm{CO}_{2}$ surface fluxes at grid point scale estimated from a global 21 year reanalysis of atmospheric measurements, J. Geophys. Res., 115, D21307, doi:10.1029/2010JD013887, 2010.

Ciais, P., Peylin, P., and Bousquet, P.: Regional biosphere carbon fluxes as inferred from atmospheric $\mathrm{CO}_{2}$ measurements, Ecological Applications, 10, 6, 1574-1589, 2000.

Deng, F. and Chen, J. M.: Recent global $\mathrm{CO}_{2}$ flux inferred from atmospheric $\mathrm{CO}_{2}$ observations and its regional analyses, Biogeosciences, 8, 3263-3281, doi:10.5194/bg-8-3263-2011, 2011.

Deng, F., Chen, J. M., Plummer, S., Chen, M., and Pisek, J.: Algorithm for Global Leaf Area Index Retrieval Using Satellite Imagery , IEEE Trans. Geosci. Remote Sens., 44, 2219-2229, 2006.

Deng, F., Chen, J.M., Yuen, C.W., Ishizawa, M., Mo, G., Higuchi, K., Chan, D., Chen, B., and Maksyutov, S.: Global monthly $\mathrm{CO}_{2}$ flux inversion with focus over North America, Tellus B, 59, 179190, 2007

Dentener, F., van Weele, M., Krol, M., Houweling, S., and van Velthoven, P.: Trends and inter-annual variability of methane emissions derived from 1979-1993 global CTM simulations, Atmos. Chem. Phys., 3, 73-88, doi:10.5194/acp-3-73-2003, 2003.

Enting, I. G. and Mansbridge, J. V.: Seasonal sources and sinks of atmospheric $\mathrm{CO}_{2}$ : direct inversion of filtered data, Tellus $\mathrm{B}, 41$, 111-126, 1989.

Enting, I. G., Trudinger, C. M., and Francey, R. J.: A synthesis inversion of the concentration and ${ }^{13} \mathrm{C}$ of atmospheric $\mathrm{CO}_{2}$, Tellus B, 35-52, 1995.

Fang, J. Y.,Guo, Z. D., Piao, S. L., and Chen, A. P.:. Terrestrial vegetation carbon sinks in China,1981-2000. Science in China (DEarth Science), 50, 1341-1350, 2007 (in Chinese).

Feely, R. A., Takahashi, T., Wanninkhof, R., McPhaden,M. J., Cosca, C. E. Sutherland, S.C., and Carr, M.E.: Decadal variability of the air-sea co2 fluxes in the equatorial pacific ocean, DeepSea Res. 49, 2443-2469, 2006.

Gerbig, C., Lin, J. C., Wofsy, S. C., Daube, B. C., Andrews, A. E., Stephens, B. B., Bakwin, P. S., and Grainger, C. A.: Toward constraining regional-scale fluxes of $\mathrm{CO}_{2}$ with atmospheric observations over a continent: 1 . Observed spatial variability from airborne platforms, J. Geophys. Res., 108, 4756, doi:10.1029/2002JD003018, 2003.

GLOBALVIEW-CO 2 : Cooperative Atmospheric Data Integration Project - Carbon Dioxide. NOAA ESRL, Boulder, Colorado, available at: http://www.esrl.noaa.gov, 2010.

Granier, C., Petron, G., Müller, J. F., and Brasseur, G.: The impact of natural and anthropogenic hydrocarbons on the tropospheric budget of carbon monoxide, Atmos. Environ., 34, 5255-5270, 2000.

Guenther, A.: The contribution of reactive carbon emissions from vegetation to the carbon balance of terrestrial ecosystems, Chemosphere, 49, 837-844, 2002.

Gurney, K. R., Law, R. M., Denning, A. S., Rayner, P. J., Baker, D., Bousquet, P., Bruhwiler, L., Chen, Y. H., Ciais, P., Fan, S., Fung, I. Y., Gloor, M., Heimann, M., Higuchi, K., John, J., Maki,
T., Maksyutov, S., Masarie, K., Peylin, P., Prather, M., Pak, B. C., Randerson, J., Sarmiento, J., Taguchi, S., Takahashi, T., and Yuen, C. W.: Towards robust regional estimates of $\mathrm{CO}_{2}$ sources and sinkes using atmospheric models, Nature, 415, 626-630, 2002.

Gurney, K. R., Law, R. M., Denning, A. S., Rayner, P. J., Baker, D., Bousquet, P., Bruhwiler, L.,Chen, Y. H., Ciais, P., Fan, S. M., Fung, I. Y., Gloor, M., Heimann, M., Higuchi, K., John, J., Kowalczyk, E., Maki, T., Maksyutov, S., Peylin, P., Prather, M., Pak, B. C., Sarmiento, J., Taguchi, S., Takahashi, T., and Yuen, C. W.: TransCom $3 \mathrm{CO}_{2}$ inversion intercomparison: 1. Annual mean control results and sensitivity to transport and prior flux information, Tellus B, 555-579, 2003.

Gurney, K. R., Law, R. M., Denning, A. S., Rayner, P. J., Pak, B. C., Baker, D., Bousquet, P., Bruhwiler, L., Chen, Y. H., Ciais, P., Fung, I. Y., Heimann, M., John, J., Maki, T., Maksyutov, S., Peylin, P., Prather, M., and Taguchi, S.: Transcom 3 inversion intercomparison: model mean results for the estimation of seasonal carbon sources and sinks, Global Biogeochem. Cy., 18, GB1010, doi:10.1029/2003GB002111, 2004.

Gurney, K. R., Castillo, K., Li, B., and Zhang, X.: A positive carbon feedback to ENSO and volcanic aerosols in the tropical terrestrial biosphere, Global Biogeochem. Cy., 26, GB1029, doi:10.1029/2011GB004129, 2012.

Hansen, M., DeFries, R., Townshend, J. R. G., and Sohlberg, R.: UMD Global Land Cover Classification, 1 Kilometer, 1.0, Department of Geography, University of Maryland, College Park, Maryland, 1981-1994, 1998.

Houweling, S., Dentener, F., and Lelieveld, J.: The impact of nonmethane hydrocarbon compounds on tropospheric photochemistry, J. Geophys. Res., 103, 10637-10696, 1998.

Houweling, S., Breon, F.-M., Aben, I., Rödenbeck, C., Gloor, M., Heimann, M., and Ciais, P.: Inverse modeling of $\mathrm{CO}_{2}$ sources and sinks using satellite data: a synthetic inter-comparison of measurement techniques and their performance as a function of space and time, Atmos. Chem. Phys., 4, 523-538, doi:10.5194/acp-4523-2004, 2004

Intergovernmental Panel on Climate Change (IPCC), I. S. A.: The Physical Science Basis of Climate Change: changes in Atmospheric Constituents and in Radiative Forcing, Cambridge University Press, NewYork, 2007.

Jiang, F., Liu, Q., Huang, X. X., Wang, T. J., Zhuang, B. L., and Xie, M.: Regional Modeling of Secondary Organic Aerosol over China by Using WRF/Chem, J. Aerosol Sci., 43, 57-73, 2012.

Ju, W. M., Chen, J. M., Black T. A., Barr A. G., Liu, J., and Chen, B. Z.: Modelling multi-year coupled carbon and water fluxes in a boreal aspen forest, Agr. Forest Meteoro., 140, 136-151, 2006.

Krol, M., Houweling, S., Bregman, B., van den Broek, M., Segers, A., van Velthoven, P., Peters, W., Dentener, F., and Bergamaschi, P.: The two-way nested global chemistry-transport zoom model TM5: algorithm and applications, Atmos. Chem. Phys., 5, 417432, doi:10.5194/acp-5-417-2005, 2005.

Krol, M. C., Meirink, J. F., Bergamaschi, P., Mak, J. E., Lowe, D., J"ockel, P., Houweling, S., and Röckmann, T.: What can ${ }^{14} \mathrm{CO}$ measurements tell us about $\mathrm{OH}$ ? Atmos. Chem. Phys., 8, 50335044, doi:10.5194/acp-8-5033-2008, 2008.

Law, R. M., Chen, Y. H., and Gurney, K. R.: TransCom $3 \mathrm{CO}_{2}$ inversion intercomparison: 2 . Sensitivity of annual mean results to data choices, Tellus B, 55, 580-595, 2003. 
Leggett, J. A., China's greenhouse gas emissions and mitigation policies. CRS Report for Congress, 2011, available at: http: //www.fas.org/sgp/crs/row/R41919.pdf (last accessed: 18 July 2011), 2011.

Le Quéré, C., Rödenbeck, C., Buitenhuis, E. T., Conway, T. J., Langenfelds, R., Gomez, A., Labuschagne, C., Ramonet, M., Nakazawa, T., Metzl, N., Gillett, N., and Heimann, M.: Saturation of the Southern ocean $\mathrm{CO}_{2}$ sink due to recent climate change, Science 316, 1735-1738, 2007.

Le Quéré, C., Raupach, M. R., Canadell, J. G., Marland, G., Bopp, L., Ciais, P., Conway, T. J., Doney, S. C., Feely, R., Foster, P., Friedlingstein, P., Gurney, K., Houghton, R. A., House, J. I., Huntingford, C., Levy, P. E., Lomas, M. R., Majkut, J., Metzl, N., Ometto, J. P., Peters, G. P., Prentice, I. C., Randerson, J. T., Running, S. W., Sarmiento, J. L., Schuster, U., Sitch, S., Takahashi, T., Viovy, N., van der Werf, G. R., and Woodward, F. I.: Trends in the sources and sinks of carbon dioxide, Nat. Geosci., 2, 831-836, doi:10.1038/ngeo689, 2009.

Liu, L. X., Zhou, L. X., Zhang, X. C., Wen, M., Zhang, F., Yao, B., and Fang S. X.: The characteristics of atmospheric $\mathrm{CO}_{2}$ concentration variation of four national background stations in China, Sci. China Ser. D-Earth Sci., 52, 1857-1863, doi:10.1007/s11430-009-0143-7, 2009.

Maki, T., Ikegami, M., Fujita, T., Hirahara, T., Yamada, K., Mori, K., Takeuchi, A., Tsutsumi, Y., Suda, K., and Conway, T. J.: New technique to analyse global distributions of $\mathrm{CO}_{2}$ concentrations and fluxes from non-processed observational data, Tellus B, 62, 797-809, doi:10.1111/j.1600-0889.2010.00488.x, 2010.

Maksyutov, S., Machida, T., Mukai, H., Patra, P. K., Nakazawa, T., Inoue, G., Baker, D., Bousquet, P., Bruhwiler, L., Chen, Y-H., Ciais, P., Denning, A.S., Fan, S., Fung, I.Y., Gloor, E., Gurney, K.R., Heimann, M., Higuchi,K., John, J., Law, R.M., Maki, T., Peylin, P., Prather, M., Pak, B., Rayner, P. J., Taguchi, S., Takahashi, T., and Yuen, C-W.: Effect of recent observations on Asian $\mathrm{CO}_{2}$ flux estimates by transport model inversions, Tellus B, 55, 522-529, 2003.

Masarie, K. A. and Tans, P. P.: Extension and integration of atmospheric carbon dioxide data into a globally consistent measurement record, J. Geophys. Res., 100, 11593-11610, doi:10.1029/95JD00859, 1995.

McKinley, G. A., Takahashi, T., Buitenhuis, E., Chai, F., Christian, J.R., Doney, S. C., Jiang, M. S., Lindsay, K., Moore, J. K., Le Quéré, C., Lima, I., Murtugudde, R., Shi, L., and Wetzel, P.: North Pacific carbon cycle response to climate variability on seasonal to decadal timescales, J. Geophys. Res., 111, doi:10.1029/2005JC003173, 2006.

Meirink, J. F., Bergamaschi, P., Frankenberg, C., d'Amelio, M. T. S., Dlugokencky, E. J., Gatti, L. V., Houweling, S., Miller, J. B., Rockmann, T., Villani, M. G., and Krol, M. C.: Four-dimensional variational data assimilation for inverse modelling of atmospheric methane emissions: Analysis of SCIAMACHY observations, J. Geophys. Res., 113, D17301, doi:10.1029/2007JD009740, 2008.

Michalak, A. M., Hirsch, A., Bruhwiler, L., Gurney, K. R., Peters, W., and Tans, P. P.: Maximum likelihood estimation of covariance parameters for Bayesian atmospheric trace gas surface flux inversions, J. Geophys. Res., 110, D24107, doi:10.1029/2005JD005970, 2005.
Naik, V., Delire, C., and Wuebbles, D. J.: Sensitivity of global biogenic isoprenoid emissions to climate variability and atmospheric $\mathrm{CO}_{2}$, J. Geophys. Res., 109, D06301, doi:10.1029/2003JD004236, 2004.

NASA Land Processes Distributed Active Archive Center (LP DAAC): ASTER L1B, USGS/Earth Resources Observation and Science (EROS) Center, Sioux Falls, South Dakota, 2001.

Olivier, J. G. J. and Berdowski J. J. M.: Global emissions sources and sinks, in: The Climate System, edited by: Berdowski, J., Guicherit, R., and Heij, B. J., A. A. Balkema Publishers/Swets \& Zeitlinger Publishers, Lisse, the Netherlands. ISBN 905809 255 0, 33-78, 2001.

Pan, Y., Birdsey, R. A., Fang, J., Houghton, R., Kauppi, P. E., Kurz, W. A., Phillips, O. L., Shvidenko, A., Lewis, S. L., Canadell, J. G., Ciais, P., Jackson, R. B., Pacala, S., McGuire, A. D., Piao, S., Rautiainen, A., Sitch, S., and Hayes, D.: A large and persistent carbon sink in the world's forests, Science, 333, 988-993, doi:10.1126/science.1201609, 2011.

Patra, P. K., Maksyutov, S., Ishizawa, M., Nakazawa, T., Takahashi, T., and Ukita, J.: Interannual and decadal changes in the sea-air $\mathrm{CO}_{2}$ flux from atmospheric $\mathrm{CO}_{2}$ inverse modeling, Global Biogeochem. Cy., 19, GB4013, doi:10.1029/2004GB002257, 2005a.

Patra, P. K., Ishizawa, M., Maksyutov, S., Nakazawa, T., and Inoue, G.: Role of biomass burning and climate anomalies for land-atmosphere carbon fluxes based on inverse modeling of atmospheric $\mathrm{CO}_{2}$, Global Biogeochem. Cy., 19, GB3005, doi:10.1029/2004GB002258, 2005b.

Patra, P. K., Canadell, J. G., Houghton, R. A., Piao, S. L., Oh, N.-H., Ciais, P., Manjunath, K. R., Chhabra, A., Wang, T., Bhattacharya, T., Bousquet, P., Hartman, J., Ito, A., Mayorga, E., Niwa, Y., Raymond, P. A., Sarma, V. V. S. S., and Lasco, R.: The carbon budget of South Asia, Biogeosciences, 10, 513-527, doi:10.5194/bg-10513-2013, 2013.

Peters, W., Krol, M., Dentener, F., Thompson, A. M., and Lelieveld, J.: Chemistry-transport modeling of the satellite observed distribution of tropical troposheric ozone, Atmos. Chem. Phys., 2, 103-120, doi:10.5194/acp-2-103-2002, 2002.

Peters, W., Miller, J. B., Whitaker, J., Denning, A. S., Hirsch, A., Krol, M. C., Zupanski, D., Bruhwiler, L., and Tans, P. P.: An ensemble data assimilation system to estimate $\mathrm{CO}_{2}$ surface fluxes from atmospheric trace gas observations, J. Geophys. Res., 110, D24304, doi:10.1029/2005JD006157, 2005.

Peters, W., Jacobson, A. R., Sweeney, C., Andrews, A. E., Conway, T. J., Masarie, K., Miller, J. B., Bruhwiler, L. M. P., Pétron, G., Hirsch, A. I., Worthy, D. E. J., van der Werf, G. R., Randerson, J. T., Wennberg, P. O., Krol, M. C., and Tans, P. P.: An atmospheric perspective on North American carbon dioxide exchange: CarbonTracker, P. Natl. Acad. Sci. USA, 104, 18925-18930, 2007.

Peters, W., Krol, M. C., van der Werf, G. R., Houweling, S., Jones, C. D., Hughes, J., Schaefer, K., Masarie, K. A., Jacobson, A. R., Miller, J. B., Cho, C. H., Ramonet, M., Schmidt, M., Ciattaglia, L., Apadula, F., Helta, D., Meinhardt, F., di Sarra, A. G., Piacentino, S., Sferlazzo, D., Aalto, T., Hatakka, J., Strom, J., Haszpra, L., Meijer, H. A. J., van der Laan, S., Neubert, R. E. M., Jordan, A., Rodo, X., Morgui, J. A., Vermeulen, A. T., Popa, E., Rozanski, K., Zimnoch, M., Manning, A. C., Leuenberger, M., Uglietti, C., Dolman, A. J., Ciais, P., Heimann, M., and Tans, P. P.: Seven years of recent European net terrestrial carbon dioxide exchange constrained by atmospheric observations, 
Glob. Change Biol., 16, 1317-1337, 2010.

Peylin, P., Rayner, P. J., Bousquet, P., Carouge, C., Hourdin, F., Heinrich, P., Ciais, P., and AEROCARB contributors: Daily $\mathrm{CO}_{2}$ flux estimates over Europe from continuous atmospheric measurements: 1, inverse methodology, Atmos. Chem. Phys., 5, 3173-3186, 2005,

http://www.atmos-chem-phys.net/5/3173/2005/.

Piao, S. L., Fang, J. Y., Ciais, P., Peylin, P., Huang, Y., Sitch, S., and Wang, T.: The carbon balance of terrestrial ecosystems in China, Nature, 458, 1009-1013, doi:10.1038/nature07944, 2009.

Rayner, N. A., Parker, D. E., Horton, E. B., Folland, C. K., Alexander, L. V., Rowell, D. P., Kent, E. C., and Kaplan, A.: Global analyses of sea surface temperature, sea ice, and night marine air temperature since the late nineteenth century, J. Geophys. Res., 108, 4407, doi:10.1029/2002JD002670, 2003.

Rayner, P. J., Enting, I. G., Francey, R. J., and Langenfelds, R.: Reconstructing the recent carbon cycle from atmospheric $\mathrm{CO}_{2}, 13 \mathrm{C}$ and $\mathrm{O}_{2} / \mathrm{N}_{2}$ observations, Tellus B, 51, 213-232, 1999a.

Rayner, P. J., Law, R. M., and Dargaville, R.: The relationship between tropical CO2 fluxes and the El Nino-Southern Oscillation, Geophys. Res. Lett., 26, 493-496, 1999 b.

Rayner, P. J., Law, R. M., Allison, C. E., Francey, R. J., Trudinger, C. M., and Pickett-Heaps, C.: Interannual variability of the global carbon cycle (1992-2005) inferred by inversion of atmospheric $\mathrm{CO}_{2}$ and $\mathrm{d}^{13} \mathrm{CO}_{2}$ measurements, Global Biogeochem. Cy., 22, GB3008, doi:10.1029/2007GB003068, 2008.

Rödenbeck, C.: Estimating $\mathrm{CO}_{2}$ sources and sinks from atmospheric mixing ratio measurements using a global inversion of atmospheric transport, Technical Report 6, Max Planck Institute for Biogeochemistry, Jena, available at: http://www.bgc-jena. mpg.de/uploads/Publications/TechnicalReports/techreport6.pdf, 2005.

Rödenbeck, C., Houweling, S., Gloor, M., and Heimann, M.: $\mathrm{CO}_{2}$ flux history 1982-2001 inferred from atmospheric data using a global inversion of atmospheric transport, Atmos. Chem. Phys., 3, 1919-1964, doi:10.5194/acp-3-1919-2003, 2003.

Schuh, A. E., Denning, A. S., Corbin, K. D., Baker, I. T., Uliasz, M., Parazoo, N., Andrews, A. E., and Worthy, D. E. J.: A regional high-resolution carbon flux inversion of North America for 2004, Biogeosciences, 7, 1625-1644, doi:10.5194/bg-71625-2010, 2010.

Stephens, B. B., Gurney, K. R., Tans, P. P., Sweeney, C., Peters, W., Bruhwiler, L., Ciais, P., Ramonet, M., Bousquet, P., Nakazawa, T., Aoki, S., Machida, T., Inoue, G., Vinnichenko, N., Lloyd, J., Jordan, A., Heimann, M., Shibistova, O., Langenfelds, R. L., Steele, L. P., Francey, R. J., and Denning, A. S.: Weak northern and strong tropical land carbon uptake from vertical profiles of atmospheric $\mathrm{CO}_{2}$, Science, 316, 1732-1735, 10.1126/science. $1137004,2007$.
Takahashi, T., Sutherland, S. C., 5 Wanninkhof, R., Sweeney, C., Feely, R. A., Chipman, D. W., Hales, B., Friederich, G., Chavez, F., Sabine, C., Watson, A., Bakker, D. C. E., Schuster, U., Metzl, N., Yoshikawa-Inoue, H., Ishii, M. Midorikawa, T., Nojiri, Y., Kortzinger, A., Steinhoff, T., Hoppema, M., Olafsson, J., Arnarson, T. S., Tillbrook, B., Johannessen, T., Olsen, A., Bellerby, R., Wong, C. S., Delille, B., Bates, N. R., and de Baar, H. J. W.: Climatological mean and decadal change in surface ocean $p \mathrm{CO}_{2}$ and net sea-air $\mathrm{CO}_{2}$ flux over the global oceans, Deep-Sea Res. II, 56, 554-577, doi:10.1016/j.dsr2.2008.12.009, 2009.

Tian, H., Melillo, J., Lu, C. Q., Kicklighter, D., Liu, M. L., Ren, W., Xu, X. F., Chen, G. S., Zhang, C., Pan, S. F., Liu, J. Y., and Running, S.: China's terrestrial carbon balance: Contributions from multiple global change factors, Global Biogeochem. Cy., 25, GB1007, doi:10.1029/2010GB003838, 2011.

van der Werf, G. R., Randerson, J. T., Giglio, L., Collatz, G. J., Mu, M., Kasibhatla, P. S., Morton, D. C., DeFries, R. S., Jin, Y., and van Leeuwen, T. T.: Global fire emissions and the contribution of deforestation, savanna, forest, agricultural, and peat fires (19972009), Atmos. Chem. Phys., 10, 11707-11735, doi:10.5194/acp10-11707-2010, 2010.

Wang, B., Huang, J. Y., Yang, X. S., Zhang, B., and Liu, M. C.: Estimation of biomass, net primary production and net ecosystem production of China's forests based on the 1999-2003 National Forest Inventory, Scand. J. Forest Res., 25, 544-553, 2010.

Wang, S. Q., Chen, J. M., Ju, W. M., Feng, X., Chen, M., Chen, P., and Yu, G.: Carbon sinks and sources in China's forests during 1901-2001, J. Environ. Manag., 85, 524-537, 2007.

Wu, B. Y. and Huang, R. H.: Effects of the Extremes in the North Atlantic Oscillation on East Asia Winter Monsoon, Chinese J. Atmos. Sci., 23, 641-651, 1999 (in Chinese).

Zhao, M. S. and Running, S. W.: Drought-Induced Reduction in Global Terrestrial Net Primary Production from 2000 through 2009, Science, 329, 940-943, doi:10.1126/science.1192666, 2010.

Zou, X. K., Ren, G. Y., and Zhang, Q.: Droughts Variations in China Based on a Compound Index of Meteorological Drought, Clim. Environ. Res., 15, 371-378, 2010 (in Chinese). 